\title{
Institutional Reform and Discourse on Democracy in Russia*
}

Jin-Sook Ju

(Paichai University)

$\langle$ CONTENTS〉

I . Introduction

II . Institutional Reform and Ideas

III. Discourse on Democracy and Institutional Reform in Russia
1. Adaptation

2. Definition of the Situation

3. Institutional Construction IV . Conclusion

- Key words : institutional reform, idea, sovereign democracy, Russia, discourse on democracy

[ABSTRACT】

This study examines the effects of ideas on the process of institutional reform, with a particular focus on Russian case. In explaining the interaction between institutional reform and ideas, I rely on the concept of "Knightian uncertainty" proposed by Blyth. In order to examine Russia's discourse on democracy, I mainly focus on the concept of sovereign democracy. The concept of sovereign democracy demonstrates how the international norm of democracy has been adapted by the domestic contexts in Russia. This is manifested as a reinterpretation of the concept of democracy in the context of Russian history, which is distinguished from that of Western liberal democracies. The concept of sovereign democracy also allows for an interpretation of the crisis situations. The central argument of the proponents of sovereign democracy with regard to the international political situation can be

* This work was supported by the $\mathrm{N}$ ational Research Foundation of Korea(NRF) grant funded by the Korea government(M EST)(N RF-2009-362-B00004). I would like to thank the three anonymous reviewers for their hel pful suggestions. 
summarized as "Russia's falling into the periphery" and "the emergence of a unipolar order under the U.S. hegemony" in the process of restructuring of international power relations. At the same time, the concept of sovereign democracy suggests that the greatest threat in the context of domestic politics is the possibility of the reemergence of oligarchy groups and local landed gentries. Based on his interpretation of the international and domestic crises and redefinition of national interests, Surkov suggests a couple of specific policy programs for the realization of a Russian style democracy. This case illustrates how the concept of sovereign democracy and its main tenets of centralizing power and realizing a Russian style democracy have been internalized in the new political institutions.

\section{I . Introduction}

This study examines the effects of ideas on the process of institutional reform, with a particular focus on the Russian case. In general, institutional reform occurs out of the necessity to regulate objective institutional mechanisms or due to actors' strategic objectives and rational calculation. However, the two explanations have been criticized because it is extremely difficult to verify empirically an objective institutional mechanism that is not subject to actors' interpretation or objectively rational interests.

As an alternative perspective, this study focuses on the effects of ideas on institutional reform. In particular, I analyze the interaction between ideas and the construction of new institutions in a transitional society-Russia. A major focus of the analysis is the ideas of Blyth, which highlight the complete uncertainty arising from an extreme crisis situation.

At times of extreme crisis, actors may find themselves in a situation of complete uncertainty and must redefine what their interests are. In this process, ideas provide actors with a blueprint for interpreting situations, redefining their interests, and constructing new institutions. This process of interaction between ideas and institutions must be grasped as a dynamic and interactive process rather than as a one-sided process. In other words, ideas 
influence the constructing of institutions, while the institutions influence the construction of ideas simultaneously. This approach could be a useful framework for interpreting both Russia's external strategies and its domestic political strategies. Through this framework, one can put forward a more persuasive explanation for why and how Russia has been making "seemingly irrational" choices, contradicting its "objective" national interests.

In order to examine Russia's discourse on democracy, I focus on the concept of sovereign democracy ( Суверенная демократия ). ${ }^{1)}$ This concrete idea was first proposed in 2006 by Vladislav Surkov ( Владислав Сурков ), first deputy chief of staff of the Russian president. However, this concept must be understood as a result of a long process of discourse among Russian elite who were in pursuit of a new international order and state rebuilding. Before Surkov's conceptualization, President Vladimir Putin used the words several times and fundamental ideas were already being circulated throughout the 2000s. Especially since Surkov conceptualized it, the concept has emerged as a critical issue, provoking debate and controversy in the country's academic and political arenas. Focusing on this concept, I distinguish three stages in the analysis of the Russian case: adaptation of international discourse, reinterpretation of democratic ideas for its own version of democracy, and construction of new institutions based on the new ideas.

A major part of this study is an analysis of political discourses by the main actors and knowledge communities. This is complemented by an analysis of the institutional reform process and institutional mechanism, which could be viewed as a process of institutional internalization of political discourse. Therefore, this analysis examines (1) debates on "sovereign democracy," which have appeared in major academic journals, academic books, and political party publications since the mid-2000s; and (2) related statements made by the main political actors.

\section{II . Institutional Reform and Ideas}

In general, institutional reform has been studied from two different

1) Averre D erek, "'Sovereign D emocracy' and Russia's Relations with the European U nion Preview," D emokratizatsiya 2 (Spring 2007), pp. 173-190; N ikita Belykh, "The I deology of Sovereign Bureaucracy Russian," Politics and Law 5 (September-0 ctober 2008), pp. 77-83. 
approaches. One approach suggests the necessity to regulate or adjust the institutional mechanism, which is presumed to be objective, as a major source of reform. In particular, the approach focuses on the "objective" and "independent" movement of the institutional mechanism and institutional effects. This basic premise that institutions operate objectively and independently, however, has been criticized by many scholars who point out that the institutional mechanism and institutional effects could be transformed through actors' interpretation and adaptation.

The other approach sees actors' strategic goals and rational calculation as an ultimate factor for institutional change. Espoused mostly by rational choice institutionalists, this approach focuses on the "interest" of actors at the micro level. According to this approach, the relevant actors' rational, active intervention and design, rather than the institution's objectivity and independence, are largely responsible for institutional reform. This approach is based on the premise of "rational" actors who are assumed to maximize their interests by choosing the best alternative available under the condition of complete information. In general, however, such an ideal condition is rarely satisfied in reality, and it is debatable whether one can figure out "real and objective" interests of actors.

Due to these criticisms, a third approach has recently emerged, drawing attention to the effects of ideas on the process of institutional change. Elements of "ideas" include such diverse concepts as world view, normative framework, world culture, programmatic idea, collective idea, and learning. ${ }^{2)}$ In particular, a number of studies in the field of international politics have analyzed theoretically and empirically the process through which norms and ideas formed at the international level are diffused and adapted by individual states, thus affecting domestic political discourse and institutional change. ${ }^{3)}$ While theories based on this approach emphasize the importance and influence of ideas in the policy-making process, they reconstruct the process

2) John L. Campbell, "Ideas, Politics, and Public Policy," Annual Review of Sociology 28 (2002), pp. 21-38; J effrey W. Legro, "The T ransformation of Policy Ideas," American Journal of Political Science 44-3 (July 2000); Jack S. Levy, "Learning and Foreign Policy: Sweeping a Conceptual M inefield," International O rganization 48-2 (Spring 1994).

3) Andrew P. Cortell and James W. D avis, Jr., "U nderstanding the D omestic Impact of International N orms: A Research Agenda," International Studies Review 2-1 (Spring 2000), pp. 65-87; M artha Finnemore and Kathryn Sikkink, "International N orm Dynamics and Political Change," International Organization 52-4, (Autumn 1998), pp. 887-917. 
from diverse perspectives. Some focus on diffusion and homogeneity, while others focus on the domestic mechanism by which ideas are independently reconstructed, instead of being unilaterally diffused. This domestic mechanism is composed of diverse variables, such as cultural context, institutional conditions, and actors' interests.

Following the new approach, I deal with questions of how ideas are generated in a transitional society such as Russia, how "interests" are redefined by these ideas, and how institutions are either reconstructed or justified on the basis of the redefined interests. In explaining the interaction between institutional reform and ideas, the study mainly relies on the concept of "Knightian uncertainty" proposed by Blyth.

This concept of Knightian uncertainty, which was named after Frank H. Knight, a famous American economist, refers to the uncertainty under special circumstances such as political system transition and economic crisis. ${ }^{4}$ According to the more traditional concept of "uncertainty," presumed by rational choice institutionalists, the perception of objective interests is certain and what is uncertain is how to maximize them. Under a situation of Knightian uncertainty, however, what remains uncertain is not simply how to maximize interests, but more fundamentally what actors' interests are. In times of a crisis, in which existing institutions are judged to have failed and thus causing extreme uncertainty, actors cannot clearly see what their interests are. During a dynamic period such as system transition, there are no "objective" interests that can be perceived without considering the specific contexts of time and space. Under a completely novel circumstance, information tends to be distributed in a diverse and unequal way, and individual interests are defined differently according to how actors perceive and interpret structural conditions and how they react specifically to these conditions. At this phase, "interests" are ultimately determined by such cognitive elements as wants, beliefs, and desire.

In this cognitive process, ideas can offer an explanation that cannot be offered by the perspective of institution or interest. It is an explanation for how and under what conditions actors pursue new institutional construction in times of a crisis or a system transition.

4) M ark Blyth, Great Transformation: Economic I deas and Institutional Change in the T wentieth Century (C ambridge: C ambridge U niversity Press, 2002), p. 5. 
Interests can only be defined from the perspective of ideas that are held by actors themselves about the cause of uncertainty. Without a due consideration for those ideas, actors' interests and strategies have no meaning. ${ }^{5)}$ In other words, actor's interests do not exist objectively or a priori. Rather they are constructed or justified through actors' ideas.

In times of such uncertainty, actors must first analyze, define, and predict the crisis situations, before embarking on the task of reconstructing institutions through collective action. This process of mobilizing diverse perceptions about the crisis involves the formation of simplified ideas. ${ }^{6}$ These ideas reduce the uncertainty by providing actors with criteria for interpreting situations and directions for collective action, thereby exerting critical influences on the process of designing new institutional construction. In other words, the ideas present actors with a blueprint for searching alternatives by providing a heuristic for analyzing and defining diverse factors in the crisis situation as well as their correlations. According to Blyth, therefore, actors' ideas, rather than their structurally driven interests, are essential for understanding their behavior.

Based on the above theoretical approach, Blyth suggests five hypotheses. ${ }^{7}$ First, ideas reduce the uncertainty at this initial stage of creating new institutions by providing an interpretation of the nature of the crisis (uncertainty reduction). Second, ideas enable collective action and coalition building by redefining actors' interests and reconstructing their cognition of political costs and interests in times of uncertainty (coalition building). Third, actors utilize ideas as tools for contesting existing institutions, making political parties useless (institutional contestation). Fourth, ideas are used as a blueprint when constructing new institutions (institutional construction). Fifth, ideas are used as a logic of justification for constructing new institutions. Using Sikkink's terms, "ideas are implemented into institutions." "8) Sixth, ideas coordinate expectations of various actors in the process of securing institutional stability and reproducing institutions (expectational coordination).

5) Ibid., p. 32.

6) Colin $\mathrm{H}$ ey, "Crisis and the Structural Transformation of the State: Interrogating Processes of Change," British J ournal of Politics and International Relations 1-3 (0 ctober 1999).

7) Mark Blyth, op. cit., pp. 35-43.

8) Kathryn Sikkink, Ideas and Institutions, D evelopmentalism in Brazil and Argentina (Ithaca and London: Cornell U niversity Press, 1991). 
When compared to the three-stage (adaptation, implementation, and consolidation) model of ideas suggested by Sikkink, this process by which ideas are internalized into institutions corresponds to the third stage (consolidation). In other words, implemented ideas are consolidated when there emerges a wide consensus among major actor groups.

One might ask where ideas originate from. While the origin of ideas can be discussed in many different aspects, this study focuses on the aspect of interaction between international norms and domestic contexts in the Russian case. One premise is that in transitional countries such as Russia, ideas are formed in the process by which international norms are introduced into the domestic contexts. In other words, ideas are formed through the interaction between externally imported international norms on the one hand, and domestic norms and domestic actors' interests on the other hand.

In explaining the dynamics and variance in the process of adopting international norms domestically, many variables can be considered. In this study, however, particular emphasis is put on the concept of "cultural match" suggested by Checkel. ${ }^{9}$ Here, cultural match refers to the extent to which regulations internalized in international norms correspond to domestic norms as reflected in domestic discourse, the legal system, and the bureaucracy. This variable may vary widely from "positive" $(+)$, when there is a perfect match between international and domestic norms, to "neutral" $(0)$, when there is no particular domestic obstacle, to "negative" (-), when there is no matching between international and domestic norms.

When the variable of cultural match turns negative, proponents of domestic norms would oppose strongly international norms, thus undermining the negotiation structure. In this case, the institutional reforms that are contained in the international norms would not be realized. When main domestic actors who exert great influence in the policy-making process have strong preferences for domestic norms and oppose adoption of international norms, the domestic diffusion would be stalled. In such a case, ideas enshrined in international norms would be adopted only partially or marginally, rather than wholly.

In this study, I analyze the effects of ideas on institutional reform in three

9) J effrey T. Checkel, "N orms, Institutions, and N ational Identity in Contemporary Europe," International Studies Q uarterly 43 (1999), pp. 86-87. 
stages for the sake of logical and conceptual clarity, even though the interactive process between ideas and institutions is a simultaneous process in reality. The first stage is "adaptation of ideas," in which ideas are formed through the interaction between international norms and domestic norms. The second stage is "definition of situation," in which actors' interests are redefined through a reinterpretation of the situation and criticism of the existing institutions. The third stage is "institutional construction," in which new institutions are constructed as well as justified. This stage implies a relatively high level of institutionalization, in which ideas are internalized into institutions.

How can we verify these hypotheses empirically? Verifying the effects of ideas on institutional reform in a causal way is a difficult task. A majority of studies have developed two different methods of causal verification. One is a specification of actors as the leading proponents of ideas either at the individual level or at the collective level, and an analysis of their discourse. ${ }^{10}$ Main actors in the policy-making process such as politicians and intellectuals, as well as epistemic communities, perform the function of diffusing ideas, world views, and world culture through diverse channels. The other method of verification is an analysis of the way ideas are filtered through and internalized into institutions. This second method seeks to demonstrate the complicated and various effects of ideas by identifying and analyzing the elements of ideas that are internalized in the institutional mechanism. I combine these two methods, with the main method being an analysis of the main actors' discourse, complemented by a brief analysis of the institutional mechanism as a product of institutional reform.

\section{Discourse on Democracy and Institutional Reform in Russia}

The emergence process of the idea of "sovereign democracy" began with the establishment of the Putin regime in Russia. Even before Surkov refined and framed the concept, Russian President Putin himself used it several times when emphasizing the necessity to implant the democratic basic principles

10) John L. Campbell, op. cit., p. 29. 
and democratic institutions into Russia in such a way that they do not conflict with the country's political reality, traditions, and history. ${ }^{11)}$ From this point of view, the concept of sovereign democracy is a result of a long process of discourse since the country's political, economic, and international crisis in the 1990s.

After using the concept of "sovereign democracy" in an interview with a foreign reporter in 2006, Surkov specified his concept in greater detail in his article "Nationalization of Future," which was published in Expert. Since then, the concept has become Russia's political doctrine. While critical perspectives on this concept do exist - some fundamental and others marginal ${ }^{12)}$ - the concept has been connected to, and received by, a fairly wide spectrum of ideological orientations from extreme right nationalism to relatively moderate positions. Included in this concept are the core elements of the nationalist consensus formed among the network of Russian ruling elite, such as strong state, strengthening of state functions in the economic arena, equal distribution, restoration of Russia's international status as a superpower, ${ }^{13)}$ and nationalism. ${ }^{14)}$

The fact that the concept of sovereign democracy has received such positive reactions in diverse areas of discourse, including the mass media, reflects the concept's important political functions and its close association with Russia's political reality. ${ }^{15)}$ More specifically, the concept has served as an ideological

11) Alfred B. Evans Jr., "Putin's Legacy and Russia's Identity," EuropeAsia Studies 6 (August 2008), p. 900.

12) Aleksei M alashenko, "From Suslov to Surkov," Russian Politics and Law 5 (SeptemberO ctober 2008), pp. 67-71; V. M. M ezhuev, "I Would Prefer to Speak of Democratic Sovereignty," Russian Studies in Philosophy 4 (Spring 2009), pp. 26-32; Yevgeny Primakov, "H ow D emocracy Is C reated - N otes for a D ebate on Ideology and Political Culture," Russian Politics and Law 5 (September-0 ctober 2008), pp. 97-101; Georgij Bovt, "Vladislav Surkov. Pragmatic eskij Idealizm" (Vlasislav Surkov Pragmatic Idealism), Russkaja Politic eskaja Kul'tura. Vzgljad iz Jutopii (Russian Political Culture: View from U topia) (M oskva Izdatel'stvo N ezavisimaja G azeta, 2007) (in Russian).

13) Jakub M. Godzimirski, "Putin and Post-Soviet Identity - Building Blocks and Buzz W ords," Problems of Post-Communism (September/O ctober 2008), p. 23; A. A. G useinov, "A Democracy for Russia, A Russia for Democracy," Russian Studies in Philosophy 4 (Spring 2009), pp. 74-84.

14) Yuri Fedorov, "D emocratization and G lobalization: The Case of Russia 2000," Carnegie Endowment for International Peace 13 (M ay 2000), p. 14.

15) L. V. Poljakov, "Suverennaja D emokratija Politic eskij Fakt kak T eoretic eskaja Predmetnost" (Sovereign D emocracy: Political Fact as Theoretical Concrete), ON S 2 (2007), p. 59 (in Russian). 
tool for unifying widely different political forces that have accelerated since the early 2000s, and thus has been developed not only as an ideology for Putin's regime but also as a party ideology for "United Russia." ${ }^{16)}$

After Surkov refined the concept of sovereign democracy, United Russia employed it as a basic principle for the party platform in December 2006. The party chairman, Boris Gryzlov, declared "we (United Russia) aim at building a sovereign democratic state... The concept of sovereign democracy is the only alternative for Russian people, and we take it as a natural principle." ${ }^{17)}$ The chairman of Russia's Constitutional Court, Valentin Zorkin, stressed the constitutional base of the concept of sovereign democracy by stating, "Russia is a democratic sovereign state, according to its Constitution. It means that Russia is a democratic country with sovereignty and that this sovereignty is democratic." ${ }^{18)}$ In addition, many core politicians -including co-chairman of Unified Russia, Sergey Schoygu and Yury Luschkov, the secretary of defense, Sergey Ivanov, the secretary of foreign affairs, Sergey Ravrov, the mayor of Peterburg, Valentina Matvienko, and the president of Tatarstan, Mintimer Schaymiev - have explicitly declared their support for sovereign democracy. ${ }^{19)}$ The chairman of the Liberal Democratic Party, V. Zhirinovsky, also expressed his support for the concept, when he said, "Surkov deals with matters that are essential for understanding the modern political context, and no one other than Surkov has been able to suggest main directions for the state development with a short-term prospect." ${ }^{20)}$ This process shows that the concept of sovereign democracy has contributed to the building of a coalition government encompassing a wide range of political forces by providing them with an idea

16) V ladislav Surkov, "Suverennaja D emokratija i Edinaja Rossija" (Sovereign D emocracy and U nited Russia), Strategija Rossi 3 (Russian Strategy 3) (M arch 2006) (in Russian).

17) See comments by V oris G ryzlov in Suverennaja D emokratija. Ot I de k D octrine (Sovereign D emocracy: From Idea to D octine) (M oskva: Izdatel'stvo Evropa, 2007), p. 46 (in Russian).

18) See comments by V aletin Zorkin in Suverennaja D emokratija. Ot I dei k D octrine (Sovereign D emocracy: From Idea to D octine) (M oskva: Izdatel'stvo Evropa, 2007), p. 48 (in Russian).

19) Ibid., pp. 46-56.

20) Vladimir Zirinovskij, "Strana z ivet Po Ponjatijam i Ėto N e V segda Ploxo. Smotrja Kakie Ponjatija Russkaja Politic eskaja Kultura" (State Exists by Rationality and It Is N ot Always Bad: Rationality of Russian Political Culture), in Vzgljad I z Jutopii. Materialy 0 bsu $z$ denija v «N ezavisimoj Gazete》 (View from U topia: D iscussions in «ndependent News》) (Izdatel'stvo N ezavisimaja G azeta, 2007), p. 54 (in Russian). 
that corresponds to the ideological orientations of the Russian elite group.

What follows is a three-stage analysis of the contents of Russia's democracy discourse as specified through the debate on sovereign democracy, and their effects on institutional reform.

\section{Adaptation}

The concept of sovereign democracy demonstrates how Russia domestically has adapted the international norm of democracy.

First, Russia's political discourse does not mind using the concept of democracy; it does not emphasize only the Russian peculiarity disconnected from international norms. In this respect, the discourse on sovereign democracy strives incessantly to achieve universality and generality. In other words, it is perfectly understood that Russia must be viewed as a case of universal democracy. As Surkov argued, "As exemplified by the fact that the German democracy differs from the French democracy not in essence but in the peculiar ways that they operate, there exist diverse traditions and diverse forms of democracy." ${ }^{21)}$ In order to justify the institutional reform, he also compares Russia, directly or indirectly, with the history of Western European political systems and Western European politicians. For instance, as a rationale for strengthening presidential power, he mentions the U.S. presidential system and the French semi-presidential system. In the same vein, Putin's institutional reform is compared with that of U.S. President Roosevelt. The control of the Duma by United Russia and the party's rapid growth are emphasized as general phenomena, as the former is compared with American political parties' control of Congress, and the latter with the rapid growth of the German Christian Democratic Party. It is often argued that Russia's totalitarian history in the twentieth century should be interpreted as universal phenomena, comparable to Germany's history under Hitler, Italy's history under Mussolini, and Spain's history under Franco. ${ }^{22)}$

21) Vladislav Surkov, "Byt' Svobodnoj N aciej Sredi Svobodnyx N acij” (Be a Free Nation under Free N ations), in Vladislav Surkov, T eksty 97-07(T ext 97-07) (M oskva Evropa, 2008), p. 116 (in Russian).

22) Vladislav Surkov, "Suverenitet _Politic eskij Sinonim Konkurentosposovnosti" (Sovereignty _Political Synonym for Ability to Practice), in Vladislav Surkov (2008), op. cit., p. 127 (in Russian). 
The Russian elite group's strong support for a market economy, in particular, clearly demonstrates that Russia's political discourse does not totally deny the concept of "democracy." It also reflects the Russian elite's selective adoption of democracy, as the country maintains a pro-Western position in cooperation for economic development, while refusing to be absorbed into the Western style liberal democracy. This emphasis on universality and selective adoption of democratic ideas may be a reflection of the coercive power of international norms. In other words, transitional societies like Russia are not completely free from the pressure to adopt international norms, and therefore international norms cannot help being introduced into the domestic context in one way or another.

At the same time, however, the concept of sovereign democracy also demonstrates how international norms are combined with domestic norms, thus resulting in new ideas. This is manifested in the reinterpretation of the concept of democracy in the context of Russian history, which is distinguished from that of Western liberal democracies.

The central tenet of sovereign democracy is that "there is no universal democracy; there are only peculiar forms of democracies reflecting the tradition, political culture, and psychology of individual states." ${ }^{23)}$ From this perspective, Surkov deals with the question of what form Russian style democracy, as distinguished from Western European liberal democracy, should take. According to him, the Russian democracy, while rooted in the European style of democracy, should be a different version reflecting the peculiar Russian civilization, and thus should be nationalistic in nature. The criticism of the Western style democracy centers on the concept of "liberty." "Liberty" or "liberal" is viewed as the main enemy, which resulted in the intervention of US hegemony and the destruction of the Russian statehood. In the view of Surkov, "Liberals are believed to have destroyed their own state."24)

Therefore, Surkov believes that it is necessary to see the typical and deeply rooted characteristics of Russian culture in order to understand the practical form of Russian democracy. Here, Russian culture is defined as "a priori

23) V. Iu. Surkov, "Commentaries on the Discussion of 'Paragraphs pro Sovereign D emocracy'," Russian Studies in Philosophy 4 (Spring 2009), p. 90.

24) Andranik M igranjan, "Istoric eskie Korni Suverennoj D emokratii" (H istorical Background of Sovereign Democracy), in Suverennaja Demokratija. Ot idei k doctrine (Sovereign D emocracy: From I dea to D octrine) (M oskva: Izdatel'stvo Evropa, 2007), p. 14 (in Russian). 
synthesis beyond empirical analysis, idealism beyond pragmatism, intuition beyond reason, and a whole beyond parts." Surkov also argues that the history of the Soviet and Russian empire should be taken as a natural cultural heritage. Formal and external regulations are important, but they can be executed only in the context of traditions and cultural factors.

With this cultural heritage as a background, Russia's sovereign democracy has the following three characteristics: "political unity through the centralization of power, idealism in the goal of political struggle, and personalization of political institutions." ${ }^{25)}$ Russian democracy is characterized not by division but by unity, and the president is viewed as the center and balancer of such unity and concentration. Therefore, Russia's sovereign democracy does not consider pluralism as an essential element of democracy. In the Russian context, pluralism is identified as the influence of oligarchy group and foreign organizations, and thus pictured as something negative. The third characteristic, the personalization of political institutions, is interpreted as an emphasis on leaders and their importance as actors. According to Surkov, the importance of personal factors has become a major institution in the Russian culture, and this cultural element must be accepted. Party platforms and doctrines are important, but they become truly meaningful only through charismatic leaders. Such arguments provide a rationale for Russia's centralized power structure. ${ }^{26)}$

In the context of discourse on sovereign democracy, the concept of autocracy is often employed not as the opposite of democracy, but rather as an inevitable path or an essential element for the building of sovereign democracy. Professor Aleksandr Dugin at Moscow National University declared, "The establishment of dictatorship in Russia during the period of $2007-2008$ was inevitable. What we are facing today is not a question of 'dictatorship or not' but a question of 'what kind of dictatorship'." According to Dugin,

it is Putin's mission to decide the form of dictatorship and its new directions. The reelection of Putin in 2008 will create a political

25) V. Iu. Surkov, op. cit., p. 12.

26) D. V. N ovikov, “Antizapadnic estvo Kak Strategija Racional'nogo Povedenija Rosijskoj Elity" (Anti-W esternism as Rational Strategy of Russian Elite), ON S (2007), p. 26 (in Russian); A. A. Guseinov, "A Democracy for Russia, A Russia for Democracy," Russian Studies in Philosophy 4 (Spring 2009), p. 79. 
situation in which he can clean up the trace of Yeltsin forces based on 'liberal democratic' interests, such as Western Europeanists, reformists, and Oligarchies and their families. After that, he may lay the foundation for the dictatorial system of the future, and unite diverse political forces into the imperial-patriotic line for such goals as a historical revenge, strengthening of Russian sovereignty, and new geopolitical dynamics. ${ }^{27)}$

Karapetjan, a renowned Russian legal scholar, also does not see any contradiction between the two concepts of dictatorship and democracy, although he does not explicitly endorse a dictatorial system. ${ }^{28)}$ According to him, the parallel usage of dictatorship and democracy is possible, as the people are the holders of national sovereignty and the realization of popular democracy is based on the dictatorship of laws and their peculiar application.

This reinterpretation of the concept of democracy is going on in the historical context, and especially by shedding new light on Soviet history. According to Surkov, Soviet history should be evaluated as a great achievement in two respects. One is the enormous ideological influence the Soviet Union exerted on the world in economic, material, and moral aspects. Through this influence, the Soviet Union contributed to the liberation movement of former colonies, and the strengthening of social balance in Western European countries. The other historical contribution of the Soviet Union is the country's industrialization. Despite this great achievement, the inevitable collapse of the Soviet Union was caused not simply by the absence of liberty and equality, but also by the emergence of elite groups and party bureaucrats who abused the merits of the system for personal purposes, and the inefficiency resulting from such abuse. Furthermore, Surkov considers the history of the Soviet system as an extension of Russian democracy, in that the Soviets operated on the ideological basis of liberty and equality. According to him, the Soviet Union "contained the seeds of democracy, declared it, and gave it a shape through language. Therefore, this language should be completed sooner or later. ${ }^{\prime 29)}$ As one of the central proponents of sovereign

27) A. Dugin, "Renessans Diktatury" (Renaissance of Dictatorship), LG (6-12 September 2006) (in Russian).

28) L. M. Karapetjan, Politic ekkie Partii v Sud'be Rossii (Political Parties in Russia's D estiny) (Sankt-Peterburg: Juridic eskij Centr Press, 2009), p. 138 (in Russian). 
democracy, Dmitrij Orlov emphasizes the importance of utilizing the experiences and traditions of Soviet history (and the modernization project, in particular) in the context of real political practice. ${ }^{30}$

In addition, the series of color revolutions in post Soviet countries were one of the most important external factors during the adaptation process. The Rose Revolution in Georgia (2003), the Orange Revolution in the Ukraine (2004), and the Tulip Revolution in Kyrgyzstan have resulted in the strengthening of autocratic tendencies in Russia. ${ }^{31)}$ The color revolutions have evoked noticeable anxiety about the possibility of similar efforts for a regime change in Russia. ${ }^{32)}$ Russian elite groups' perception of the color revolutions could be summarized as illegality, instability, and insecurity as well as threat of extremism. Based on such perception, the absolute priority for the Russian elite group was not the enhancing of democracy, but the strengthening of the state through control and stability at the center.

In sum, the Russian elite group is adopting the idea of democracy selectively and marginally, rather than wholly and comprehensively. Applying Checkel's concept of "cultural match," it seems to be close to a negative case. The international norms of democracy do not match well with the historical and cultural context of Russian domestic society. Faced with the resistance from the Russian elite, the international norms appear to have been adopted only selectively.

\section{Definition of the Situation}

The concept of sovereign democracy, as it is based on the reinterpretation of the concept of democracy, also allows for an interpretation of crisis situations. More specifically, the concept of sovereign democracy first interprets the following two crisis situations: the restructuring of a new international order

29) Vladislav Surkov (2008), op. cit., p. 127.

30) D mitrij O rlov, "Politic eskaja Doktrina Suverennoj D emokratii" (Political Doctrine of Sovereign D emocracy), in Suverennaija D emokratija. Ot idei k doctrine (Sovereign D emocracy: From Idea to D octrine) (M oskva: I zdatel'stvo Evropa, 2007), p. 8 (in Russian).

31) Irina Kobrinskaya, "Russia - NIS Relations Beyond the Color Revolutions: Are the Shifts Durable?" PO N ARS Policy M emo 375, Foundation for Prospective Studies and Initiatives (D ecember 2005).

32) Gail W. Lapidus, "Between Assertiveness and Insecurity: Russian Elite Attitudes and the Russia-G eorgia Crisis," Post-Soviet Affairs 23-2 (2007), p. 140. 
and the domestic political transition.

Nearing the end of the Yeltsin regime, Russia was confronted externally with a dramatic fall in its international status as well as an economic collapse (i.e., national insolvency in 1997). Internally, Russia also had to resolve the serious problem of reconstructing the state after experiencing the second Chechen war and a series of terrorist attacks in 1999.

What is suggested as the most important and serious task in such a crisis situation is the maintenance of external state sovereignty and the strengthening of internal sovereignty. In his article, "Russian Political Culture," published in 2007, Surkov asks the following questions in a rather demagogical tone: "The reason why (Western powers) approach Russia is to purchase oil, gas, and lumber. In the international division of labor, we are far from engineers, bankers, designers, and producers. We are just oil drilling workers, drivers, and woodcutters... But why should it be the case? Aren't we the nation that takes pride in a high quality education and a high cultural level?"33)

What the concept of sovereign democracy concentrates foremost on is the interpretation of the international political situation and the redefining of Russian interest. The central argument of the proponents of sovereign democracy with regard to the international political situation can be summarized as "Russia's falling into the periphery" and "the emergence of a unipolar order under the US hegemony" in the process of restructuring of international power relations. "The global balance has been destroyed, and one empire is building its own ideological system in order to rule the world." Sovereign democracy, then, is put forward as a concept resisting U.S. hegemony in terms of both ideology and foreign policy. ${ }^{34)}$ In the midst of globalization and worldwide competition that is threatening Russia, the country must strengthen its competitiveness by securing energy resources and utilizing the strategic communication business and energy related technologies. It is also argued that the country should pursue the modernization of its strategic nuclear forces and military forces against the security threat. In other words, with the progress of unfair globalization,

33) Vladislav Surkov, "Russkaja Politic eskaja Kul'tura. V zgljad Iz Jutopii" (Russian Political Culture: View from U topia), in Vladislav Surkov (2008), op. cit., p. 26 (in Russian).

34) Andranik M igranjan, op. cit., p. 12. 
Russia needs sovereignty in order to have sufficient competitiveness, and global energy security is a way to secure Russia's sovereignty. ${ }^{35)}$ Here, the concept of sovereignty symbolizes Russia's strategic approach to globalization. "Russia has to participate in producing fair rules of globalization. It must veto a monopoly by one or two countries in such areas that could determine the survival of states, and support the building of new communication and transportation system, and the establishment of a high-technology international center." $\left.{ }^{36}\right)$

At the same time, the concept of sovereign democracy provides an interpretation for the domestic crisis. Here, such an interpretation centers around the concept of liberalism. "We witnessed a tyranny of radical liberalism during the period of the Yeltsin regime, when the ruling power

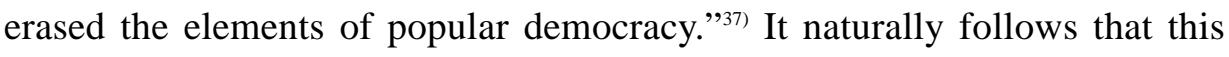
period is harshly criticized. Those politicians who represented radical liberalism in the 1990s are now pictured as an elite group composed mainly of a coalition of oligarchies and bureaucrats who detested the people. The concept of sovereign democracy, then, suggests that the greatest threat in the context of domestic politics is the possibility of the reemergence of oligarchy groups and local landed gentries. The oligarchy forces are interpreted by the concept of sovereign democracy as the product of liberal evils, signified by the reduction of state intervention. According to this interpretation, the oligarchy group seized power in an unfair manner by swiftly replacing the nomenklatura when the state control was lost and irresponsibility and disorder prevailed. Surkov associates the formation of the oligarchy group and the prevalence of corruption with the concept of "liberty." "The word, liberty, has special meanings. Dominant TV channels were owned by several oligarchy groups, who participated in dividing up the new state property. These channels are mainly used as a decoration for these oligarchy groups," he argues. ${ }^{38)}$ The concept of liberty is also used as a tool for criticizing the Russian federal system. Surkov asks, "Is this chaotic situation, in which a

35) D mitrij 0 rlov, op. cit., p. 5.

36) Vladislav Surkov, "Suverenitet _ Politic eskij Sinonim Konkurentosposovnosti" (Sovereignty Political Synonym for Ability to Practice), in Vladislav Surkov (2008), op. cit., p. 138 (in Russian).

37) L. M. Karapetjan, op. cit., p. 138.

38) Vladislav Surkov (2008), op. cit., p. 130. 
number of federal states attempt to break away from the federation and to become independent states, liberty?" Then he suggests that in order to fight off this situation, national level elite forces must be formed and a coalition of wide and diverse political forces must be built. ${ }^{39}$

Putin also criticizes the district-level simple plurality electoral system, as it "could not prevent local landed gentries from electing their candidates by mobilizing their administrative resources." He then suggests pure proportional representation (PR) as an alternative that could democratize the electoral system by minimizing such problems. ${ }^{40)}$ It is argued that the new institution (that is, the PR system) has contributed to improving the quality of the Russian political system, not only by increasing the influence of political parties in the process of forming a democratic government, but also by intensifying party competition in that process.

In sum, the concept of sovereign democracy provides the Russian elite with important ideological guidance and a framework in the process of interpreting the new crisis situations arising from the democratic transition and globalization and of redefining national interests.

\section{Institutional Construction}

According to Blyth's hypotheses, ideas are not simply weapons for criticizing and attacking the existing order and institutions, but also offer a blueprint for constructing a new institutional order after destroying the old one. The concept of sovereign democracy performs this constructive function for Russia.

Based on his interpretation of the international and domestic crises and redefinition of national interests, Surkov suggests a couple of specific policy programs for the realization of a Russian style democracy. ${ }^{41)}$ His policy programs provide not only a logic for justifying the institutional reform of the Putin regime, but also a direction for the subsequent institutional reform process. First, Surkov suggests that the whole territory of Russia be united

39) D mitrij O rlov, op. cit., p. 9.

40) V. V. Putin, "Poslanie Federal'nomu Sobranija R ossijskoj Federacii 26 Aprelja 2007 goda" (Speech to Congress of the Russian Federation 26 April 2007), in V. V. Putin, I zbrannye Reci i Vystuplenija (Speeches Collection) (M oskva: Kniznyj M ir, 2008), p. 408 (in Russian).

41) V ladislav Surkov (2008), op. cit., p. 12. 
under the sole and centralized state, and that the president exercise power over the governors of federal states. This way, centralized control of the federal states' administration and budget system could be constructed. Second, Surkov suggests that dispersed political forces be integrated into strong, national-level political parties with the adoption of a PR system for the Duma election. He also recommends banning small political parties based on regions, religions, and occupations, so that political parties not only differentiate voters according to ideologies and issue positions, but also contribute to integrating the entire people through common, shared values. In other words, he emphasized the importance of maintaining the principles of the Russian style multi-party system, in which voters are divided, yet the people are integrated. In order to justify this policy of centralizing power and strengthening presidential power, Surkov compares US President Roosevelt in the 1930s and Russian President Putin in the 1990s. His argument is that under an economic crisis a centralization of power through the strengthening of administrative organizations and presidential power is inevitable.

As demonstrated by the above policy proposals, the main direction of party system reform, suggested by the concept of sovereign democracy, implies clearly the exclusion of liberal opposition party forces. Orlov judges that the revised election laws "have contributed to isolating anti-regime opposition parties such as Michail Kashjanov's party and to institutionalizing parliamentary opposition parties." ${ }^{42)}$ In addition, they have laid the foundation for the emergence of a new majority party (United Russia) led by Putin. According to Putin, this majority party has the central function of "realizing national policies through laws, decrees, and orders." ${ }^{433}$

A similar vision of institutional reform appeared in Putin's speech, announced in October 2006, and it is no coincidence that Surkov's concept of sovereign democracy and policy proposals were also publicized around that time. According to Putin, the main issue in local institutional reform should be the stabilization of state power, and the issue of constructing a socioeconomic complex over the whole territory should be viewed from this perspective of

42) D mitrij 0 rlov, op. cit., p. 8.

43) V. V. Putin, “Vstupitel'noe Slovo na VIII s'ezde Partii 《Edinnaja Rossija》 10 ktjabrja 2007 Goda" (Speech at the 8th Party Congress «United Russia» 10 ctober 2007), in V. V. Putin, op. cit., p. 353. 
state development. More specifically, it refers to "completing a mechanism that links the central and local administrative powers in various areas." ${ }^{\left.{ }^{44}\right)}$ While Putin set the strengthening of local autonomy as one of the main goals in state strategy, he also emphasized that this strengthening of local governments should be accompanied by the building of an objective system, which would not only make local governments work effectively and but also lead to an increase in the federal government's responsibility. ${ }^{45)}$

As an important institutional device for securing hierarchy in power relations and strengthening political parties, reform of the electoral system was pursued with the guidance of Putin's consistent political intention and vision. Entering the 2000s, Putin initiated a series of institutional reforms directed to the goal of building a strong state. Examples include a revised political party law, giving political parties an exclusive right to participate in the PR system (2001), prohibiting social groups' electoral participation (2003), raising the minimum number of members when establishing a party (2004), and prohibiting Duma representatives from withdrawing from a negotiating bloc (2004). ${ }^{46)}$ On September 13, 2004, Putin proclaimed his will to "form a government based on the legislative support." In addition, there was much discussion of the necessity to control the legislative branch so that it remained pro-government, and this policy goal was pursued together with a comprehensive reform of the executive branch. ${ }^{47)}$

At the local level, institutional changes, such as the abolition of direct elections for the head of federal states and change in the local legislative electoral system from a pure simple plurality system to a mixed system, contributed to the strengthening of vertical hierarchical relations between the center and the regions. The introduction of a PR system in local elections helped to strengthen the local party structure, and local administrative heads'

44) V. V. Putin, "V stupitel'noe Slovo na Zasedanii Gosudarstvennogo Soveta. 21 ijulja 2006 goda" (Speech at the N ational Committee M eeting 21 July 2006), in Ibid.

45) V. V. Putin, "Poslanie Federal'nomu Sobraniju Rossijskoj Federacii 26 Aprelja 2007 goda" (Speech to the Congress of the Russian Federation 26 April 2007), in I bid., p. 411.

46) B. Makarenko, "N ovyj Zakon o Vyborax i Ėvoljucija Rez ma" (New Election Law and Evolution of Regime), Pro et Contra 31-1 (2006), p. 100 (in Russian).

47) I. I. Kuznecov, Pravitel'stvo Parlamenskogo D overija v Strategi i Reform I zbirate'noj Sistemy Rossii (Parliamentary Government in Reform Strategy of Russia's Electoral System) (Saratov: Vestnik Povolz. Akad. Gos. Sluzby, 2005), p. 11 (in Russian). 
active participation in the so-called power political party (that is, United Russia), resulted in a concentration of a local elite network. ${ }^{48)}$ Interestingly, the effect of the strengthening party system was greater in regions with an authoritarian and monopolistic party system than in regions with a competitive party system. This finding seems to imply that the strengthening of political parties might have been utilized as an effective device for power concentration. ${ }^{49)}$ With these institutional changes, many different independent channels that had been used to control interdependent relations between the center and regions were closed. Subsequently, local administrative heads, as the exclusive channel to the center, could secure strong control over the local executive. ${ }^{50}$

This whole process of institutional reforms was executed with the full support of the elite group. For example, since Putin proposed the reform of abolishing direct elections for local executive heads and introducing an appointment system instead, it took only three months for this reform to be enacted by the Duma without any resistance. Goode demonstrates how the justification arises from Russian traditions of national integration. ${ }^{51)}$

At that time, a substantive power integration was already achieved quite successfully, as exemplified by the fact that 88 percent of local executive heads belonged to United Russia. And contrary to general expectations, these local heads preferred the maintenance of the interest structure through an appointment system. This kind of active conformity and agreement on the part of the elite group was also confirmed in the revision of electoral laws in 2004, which entailed a change from a mixed system to a pure PR system for the goal of building a strong and effective party system. ${ }^{52}$

48) P. V. Panov, “Reforma Regional'nyx System i Razvitie Politic eskix Partij v Regionach Rossii" (Reform of Regional System and Development of Russian Regions), POLIS 5 (2005), p. 107 (in Russian).

49) Ibid., p. 115.

50) V. V. Lapkin and V. I. Pantin, "Politic eskie Transformacii v Rossii i na U kraine v 20042006 gg.: Pric iny v Vozmoz nye Posledstvija" (Political Transformation in Russia and U kraine in 2004-2006: Reasons for Possible O utcomes), POLIS 1 (2007), p. 107 (in Russian).

51) J. Paul Goode, "The Puzzle of Putin's Gubernatorial Appointments," EuropeAsia Studies 3 (M ay 2007), pp. 374-379.

52) Jin-Sook Ju, "Leosiayj Seoungeo Jedo Gaeheok: Kwonrouk Kwangye, H waksan, Jedobyounwha" (Electoral System Reform in Russia: Power Relations, Diffusion and Institutional Change), Gugje Jeongchi N onchong (The Korean Journal of International Relations) 49-4 (2009), pp. 165-190 (in Korean). 
In the legislative election held on December 2, 2007, the effects of these reforms in electoral laws and political party laws were quite visible. In the 2007 election, a total of 11 political parties participated, and 63.71 percent of eligible voters cast their ballots, resulting in an around 8 percent increase in turnout from the 2003 election. United Russia, which had received 37.57 percent of the total votes in 2003, was able to garner 64.3 percent of the total votes in 2007, thus securing 315 Duma seats or 70 percent of the total seats. This represented an increase of 92 seats from the 2003 election outcome. The vote share for the Communist Party was 11.6 percent, and the party secured 57 seats, an increase of a mere 5 seats from the 2003 election. The Liberal Democratic Party recorded a vote share of 8.2 percent, and secured 40 seats, an increase of 4 seats. "A Just Russia" Party had a vote share of 7.8 percent and 38 seats.

Considering that the Liberal Democratic Party and "A Just Russia" are maintaining their pro-government lines, one might say that United Russia is controlling 393 seats out of 450 seats, a share of 87 percent, leaving the opposition forces only with 57 seats (13 percent). This dramatic increase in the vote share for United Russia was expected by many experts, and it can be explained largely by the aforementioned institutional change from a mixed electoral system to a pure PR system.

This case illustrates how the concept of sovereign democracy and its main tenets of centralizing power and realizing a Russian style democracy have been internalized in the new political institutions. In other words, the institutional reform is accompanied by the process of idea building, which provides a logic of justification and an ideological base for the institutional reform. The cognitive internalization of institutions could be interpreted as a relatively high level of institutionalization as well as a signal of effective functioning of these institutions.

\section{Conclusion}

This study attempted to analyze the effects of ideas on institutional reform through a case study of the Russian discourse on democracy and institutional reform in the 2000s. With a focus on the concept of sovereign democracy, the 
study analyzed the Russian elite group's discourse on democracy, and then demonstrated how this concept provided the elite group with a reinterpretation of the crisis situation, a redefinition of their interests, and a blueprint for new institutional construction. The concept of sovereign democracy is a result of a long process of discourse in Russia since the international and domestic crises in the 1990s, and it conceptualizes the Russian consensus on the new international order and the state rebuilding. The interactive process between the idea and institutional reform is to be understood as a simultaneous process, in which the construction of institutions and the building of ideas influence each other. Reflecting the particularity of a transitional society, the study also employed a strategy of analyzing the case in three stages. Despite the simultaneity of this process in reality, the analysis was composed of three successive stages for technical reasons. The three stages consisted of (1) adaptation, in which ideas are domestically received through interaction between international norms and domestic norms, (2) definition of situation, in which the crisis situations are reinterpreted on the basis of ideas, and (3) institutional construction, in which new institutions are constructed on the basis of a reinterpretation of the situation.

At the first stage of adaptation, the concept of sovereign democracy demonstrates how the universal concept of democracy has been reinterpreted and adapted in the context of Russia's cultural and historical traditions. Since the international norm of democracy did not fit well with Russian domestic norms, the norm of democracy had to be adopted only selectively and marginally. Applying Checkel's concept of "cultural match," Russia could be classified as a negative case.

In correspondence with the first stage, at the second stage of definition of situation, the concept of sovereign democracy offers a new interpretation of the crisis situations facing Russia. First, the current situation, as it is characterized externally by constructing a new international order and internally by the state rebuilding, is viewed as a crisis situation involving extreme uncertainty. Then, after diagnosing the core of the crisis as US hegemony and Russia's falling into the periphery, the concept was put forward for securing and strengthening of both external and internal sovereignty as the only alternative.

Finally, at the stage of institutional construction, the concept provides a 
blueprint for new institutions based on the principles of centralization and hierarchical order. This also corresponds to the massive institutional reform that has been occurring in Russia since the mid-2000s. The concept of sovereign democracy not only provides a strong justification for the former institutional reform, but also signals the cognitive internalization of these institutions.

Admittedly, this study may require further methodological refinement. Nevertheless, the three-stage analysis not only demonstrates close interactions between Russia's institutional reform and ideas, but also verifies to some extent the effects of ideas on institutional construction.

\section{REFERENCES}

Belykh, Nikita. "The Ideology of Sovereign Bureaucracy Russian.” Politics and Law 5. September-October 2008, pp. 77-83.

Blyth, Mark. Great Transformation: Economic Ideas and Institutional Change in the Twentieth Century. Cambridge: Cambridge University Press, 2002.

Bovt, Georgij "Vladislav Surkov. Pragmatic eskij Idealizm" (Vladislav Surkov Pragmatic Idealism). Russkaja Politič eskaja Kul'tura. Vzgljad iz Jutopii (Russian Political Culture -View from Utopia). Moskva Izdatel'stvo Nezavisimaja Gazeta, 2007 (In Russian).

Campbell, John L. "Ideas, Politics, and Public Policy." Annual Review of Sociology 28. 2002, pp. 21-38.

Checkel, Jeffrey T. "Norms, Institutions, and National Identity in Contemporary Europe.” International Studies Quarterly 43. 1999, pp. 86-87.

Cortell, Andrew P. and James W. Davis, Jr. "Understanding the Domestic Impact of International Norms: A Research Agenda." International Studies Review 2-1. Spring 2000, pp. 65-87.

Derek, Averre. "Sovereign Democracy' and Russia's Relations with the European Union: Preview." Demokratizatsiya 2. Spring 2007, pp. 173-190.

Dugin, A. "Renessans Diktatury" (Renaissance of Dictatorship). LG. 6-12 September 2006 (In Russian).

Evans, Alfred B. Jr. "Putin's Legacy and Russia's Identity." Europe-Asia 
Studies 6. August 2008.

Fedorov, Yuri. "Democratization and Globalization: The Case of Russia 2000." Carnegie Endowment for International Peace 13. May 2000, p. 14.

Finnemore, Martha and Kathryn Sikkink. "International Norm Dynamics and Political Change.” International Organization 52-4. Autumn 1998, pp. 887917.

Godzimirski, Jakub M. "Putin and Post-Soviet Identity -Building Blocks and Buzz Words.” Problems of Post-Communism. September/October 2008, p. 23.

Goode, J. Paul. "The Puzzle of Putin's Gubernatorial Appointments." Europe-Asia Studies 3. May 2007, pp. 374-379.

Guseinov, A. A. "A Democracy for Russia, A Russia for Democracy." Russian Studies in Philosophy 4. Spring 2009, pp.74-84.

Hey, Colin. "Crisis and the Structural Transformation of the State: Interrogating Processes of Change." British Journal of Politics and International Relations 1-3. October 1999.

Karapetjan, L. M. Politič eskie Partii v Sud'be Rossii (Political Parties in Russia's Destiny). Sankt-Peterburg: Juridic eskij Centr Press, 2009 (In Russian).

Kobrinskaya, Irina. "Russia-NIS Relations Beyond the Color RevolutionsAre the Shifts Durable?" PONARS Policy Memo 375. Foundation for Prospective Studies and Initiatives. December 2005.

Kuznecov, I. I. Pravitel'stvo Parlamenskogo Doverija v Strategii Reform Izbiratel'noj Sistemy Rossii (Parliamentary Government in Reform Strategy of Russia's Electoral System). Saratov: Vestnik Povolž. Akad. Gos. Sluzby, 2005 (In Russian).

Ju, Jin-Sook. "Leosiayj Seoungeo Jedo Gaeheok: Kwonrouk Kwangye, Hwaksan, Jedobyounwha" (Electoral System Reform in Russia: Power Relations, Diffusion and Institutional Change). Gugje Jeongchi Nonchong (The Korean Journal of International Relations) 49-4. 2009, pp. 165-190 (In Korean).

Lapidus, Gail W. "Between Assertiveness and Insecurity: Russian Elite Attitudes and the Russia-Georgia Crisis." Post-Soviet Affairs 23-2. 2007, pp. 138-155. 
Lapkin V. V. and V. I. Pantin. "Politic eskie Transformacii v Rossii i na Ukraine v 2004-2006 gg.: Prič iny v Vozmož nye Posledstvija" (Political Transformation in Russia and Ukraine in 2004-2006: Reasons for Possible Outcomes). POLIS 1. 2007, p. 107 (In Russian).

Legro, Jeffrey W. "The Transformation of Policy Ideas." American Journal of Political Science 44-3. July 2000.

Levy, Jack S. "Learning and Foreign Policy: Sweeping a Conceptual Minefield." International Organization 48-2. Spring 1994.

Makarenko, B. "Novyj Zakon o Vyborax i Èvoljucija Reżma" (New Election Law and Evolution of Regime). Pro et Contra 31-1. 2006, p. 100 (In Russian).

Malashenko, Aleksei. "From Suslov to Surkov." Russian Politics and Law 5. September-October 2008, pp. 67-71.

Mezhuev, V. M. "I Would Prefer to Speak of Democratic Sovereignty." Russian Studies in Philosophy 4. Spring 2009, pp. 26-32.

Migranjan, Andranik. "Istoric eskie Korni Suverennoj Demokratii" (Historical Background of Sovereign Democracy). In Suverennaja Demokratija. Ot idei k doctrine (Sovereign Democracy: From Idea to Doctrine). Moskva: Izdatel'stvo Evropa, 2007, p. 12 and p. 14 (In Russian).

Novikov, D. V. “Antizapadnić estvo Kak Strategija Racional'nogo Povedenija Rosijskoj Elity" (Anti-Westernism as Rational Strategy of Russian Elite). ONS. 2007, p. 26 (In Russian).

Orlov, Dmitrij. "Politić eskaja Doktrina Suverennoj Demokratii" (Political Doctrine of Sovereign Democracy). In Suverennaija Demokratija. Ot idei k doctrine (Sovereign Democracy: From Idea to Doctrine). Moskva: Izdatel'stvo Evropa, 2007, p. 5 and pp. 8-9 (In Russian).

Panov, P. V. "Reforma Regional'nyx System i Razvitie Politic eskix Partij v Regionach Rossii" (Reform of Regional System and Development of Russian Regions). POLIS 5. 2005, p. 107 (In Russian).

Poljakov, L. V. "Suverennaja Demokratija Politic eskij Fakt kak Teoretic eskaja Predmetnost" (Sovereign Democracy: Political Fact as Theoretical Concrete). ONS 2. 2007, p. 59 (In Russian).

Primakov, Yevgeny. "How Democracy Is Created - Notes for a Debate on Ideology and Political Culture." Russian Politics and Law 5. September-October 2008, pp. 97-101. 
Putin, V. V. Izbrannye Rec i i Vystuplenija (Speech Collection). Moskva: Kniz nyj Mir, 2008 (In Russian).

Sikkink, Kathryn. Ideas and Institutions, Developmentalism in Brazil and Argentina. Ithaca and London: Cornell University Press, 1991.

Sovereign Democracy: From Idea to Doctrine. Moscow: Europe Press, 2007 (In Russian).

Surkov, Vladislav. "Suverennaja Demokratija i Edinaja Rossija" (Sovereign Democracy and United Russia). Strategija Rossii 3 (Russian Strategy 3). March 2006 (In Russian). . Teksty 97-07 (Text 97-07). Moskva: Evropa, 2008 (In Russian). . "Commentaries on the Discussion of 'Paragraphs pro Sovereign Democracy'." Russian Studies in Philosophy 4. Spring 2009, p. 90.

Žirinovskij, Vladimir. "Strana živèt Po Ponjatijam i Ėto Ne Vsegda Ploxo. Smotrja Kakie Ponjatija Russkaja Politic eskaja Kultura" (State Exists by Rationality and It Is Not Always Bad: Rationality of Russian Political Culture). In Vzgljad Iz Jutopii. Materialy Obsuzdenija v «Nezavisimoj Gazete》(View from Utopia: Discussions in 《Independent News》). Izdatel'stvo Nezavisimaja Gazeta, 2007, p. 54 (In Russian). 